\title{
MANAGEMENT OF Allium WHITE ROT CAUSED BY Sclerotium cepivorum BY USING COMPOST OF CERTAIN PLANT WASTES \\ Shalaby, M. E. ${ }^{1}$ and G. A. El-Kot ${ }^{2}$ \\ 1 Agricultural Microbiology DepT. of Agric. Botany, Fac. of Agric., Kafrelsheikh University, Egypt. \\ 2 Plant Pathology DepT. of Agric. Botany, Fac. of Agric., Kafrelsheikh University, Egypt.
}

\begin{abstract}
A laboratory trial was conducted at $20^{\circ} \mathrm{C}$ to investigate the effect of $\mathrm{pH}$ range on the growth and sclerotial formation of Sclerotium cepivorum, which causes white rot of Allium species. The obtained results indicated that $\mathrm{pH} 6$ followed by $\mathrm{pH} 7$ were the optimal $\mathrm{pH}$ degrees for growing the pathogen on PDA medium with production a large number of sclerotial populations. The lowest radial growth of $S$. cepivorum was observed at $\mathrm{pH} 8$ and $\mathrm{pH}$ 4. No significant differences between diameters of each sclerotia was recorded within the tested $\mathrm{pH}$ range. 100 Sclerotia were exposed in the soil to one of three concentrations (5, 10 and $15 \%)$ of composted onion, garlic and cabbage wastes under greenhouse conditions. Germination of the exposed sclerotia was determined on PDA medium in comparison with those unexposed. Failure of germination of the exposed sclerotia on PDA medium indicates damaged them within the soil in absence of the host. Due to use $15 \%$ concentration of each compost type, higher efficiency at the first 15 exposed days was obtained. After 30 exposed days, suppressive effects of all applied concentrations of each compost type against viability of the treated sclerotia were paralleled increased in comparison with almost effect showed in control. Destroyed percentages of the exposed sclerotia were approximately pointed after 45 exposed days to the investigated waste types. Whenever, maximal mean values of the destroyed sclerotia were done and reached $75.70,74.26$ and $72.26 \%$ due to use of the composted garlic, onion and cabbage wastes, respectively, in comparison with $8.30 \%$ for control in absence of the host.

Accordingly, great amounts of $\mathrm{NH}_{4}, \mathrm{NO}_{3}, \mathrm{P}, \mathrm{K}$ and $\mathrm{SO}_{4}$ were accumulated within the treated soils in comparison with the free soils from treatments. However, potential use of the composted wastes could be attributed to trick and destruction of the vast majority of sclerotia in the field, consequently reduces the risk of the pathogen spread to neighboring fields.
\end{abstract}

Keywords: S. cepivorum; growth conditions, composted wastes, destroyed sclerotia

\section{INTRODUCTION}

Allium white rot of onion (Allium cepa L.) caused by the soil-borne, sclerotium-forning, fungus, Sclerotium cepivorum Berk, is one of the most serious diseases of onions. The disease can reduce yields to uneconomic levels in 4 years of successive onion crops (Coley-Smith, 1987). For controlling Allium white rot disease, number of methods have been suggested which included fungicide application (Banks and Edgington, 1989 and Stewart et. al., 1994), soil fumigants (Entwistle, 1990), soil solarisation (Melero-Vara et. al., 2000 and McLean et al., 2001) and biological control ( 
Clarkson et al., 2002 and Clarkson et al., 2004). Sclerotium cepivorum produces no functional spores. Instead, it propagates by the production of round, poppy-seed-sized sclerotia on the roots of decayed host plants. Sclerotia spread via mass movement of soil or water and especially on infested plant parts. The white rot pathogen persists in the soil in the absence of host plants as sclerotia which can survive in this form for more than 20 years (Coley-Smith and Parfitt, 1986). Following their production, sclerotia constitutively dormant for 1-3 months and will then only germinate in the presence of host plants (Coley-Smith, 1987). Therefore, many workers have focused on the potential of germination stimulants of sclerotia in the absence of onion and garlic plants to minimize numbers of sclerotia in the soil, finally control Allium white rot (Coventry et. al., 2002, Hovius and McDonald, 2002 and Davis et. al., 2007). In the absence of a host, the fungus dies without reproducing its reproductive units. Germination of the sclerotia prior to an Allium crop, through the use of natural and synthetic stimulants, has been shown to reduce inocula levels in the field (Utkheda and Rahe, 1982 and Crowe et al., 1994). Efficiency of the disease control depends upon the method used and on the time of application, but no one method offering complete control (Melero-Vara et. al., 2000).

Under favorable environmental conditions, germination of sclerotia and host infection are stimulated by specific chemicals released by susceptible host roots (Stewart et al., 1989). Maximum germination of sclerotia occurs when soil temperatures are in between 10 and $20 \stackrel{\circ}{ }$ (Crowe and Hall, 1980). Therefore, products to stimulate the germination of sclerotia should be applied when soil temperatures remain in this range for approximately 3 months. Soil moisture is also an important factor in sclerotial germination (Crowe et al., 1994) and is necessary to ensure maximal and uniform spread of the volatile stimulant. Diallyl disulfide (DADS), a primary decomposition exudes from garlic and onion roots, is a petroleum-derived product that can stimulate the germination of sclerotia (Coley-Smith and King, 1969). The alkenyl L-cystein sulfoxides in Allium roots exudates are precursors of the volatile allyl and propyl sulfides that stimulate eruptive germination of the sclerotia after their metabolized by the soil microflora, to yield a range of volatile thiols and sulfides that activate the dormant sclerotia (Sommerville and Hall, 1987). Once the sclerotia start germination, the mycelium becomes susceptible to hyperparasitism and lysis (Utkheda and Rahe, 1982). When a sclerotium germinates and infects an Allium root, mycelia penetrate the root epidermis then invades the cortical parenchyma of the bulb, eventually destroying it. The pathogen spreads from plant to plant, increasing disease incidence within the same growing season (Crowe and Hall, 1980).

Sclerotia of $S$. cepivorum normally germinate in the presence of root exudates of Allium species, but germination can be stimulated by producing such natural onion and garlic oil, which contain the same or similar compounds as the root exudates. In addition to natural products, synthetic germination stimulants have been derived from petroleum (Crowe et al., 1994). Composted wastes and plant residues, natural and safe environmentally materials, were also utilized as potential control strategies focus on the removal of primary sclerotial inoculum of $S$. cepivorum (Coventry 
et. al., 2002 and Davis et. al., 2007). These wastes contain some compounds which are capable to induce germination of sclerotia forming by $S$. cepivorum in absence of onion (Entwistle, 1990). Against the related soil-borne pathogen Sclerotium rolfsii, composts have been also successfully used by Hadler and Gorodecki (1991).

The objective of the present work was to determine the efficacy of composted waste applications of onion, garlic and cabbage plants in reducing the survival of sclerotia formed by $S$. cepivorum, the causal pathogen of Allium white rot disease.

\section{MATERIALS AND METHODS}

\section{Effect of $\mathrm{pH}$ on growth of Sclerotium cepivorum:}

Sclerotial-forming pathogen (Sclerotium cepivorum Berk) was isolated from naturally diseased onion plants, collected from Negrig which is located at El-Gharbia Governorate during 2008 season. Plants showed sever white rot symptoms were collected and infected parts of onion bulbs were cut into small pieces. Prepared pieces were surface sterilized by dipping in $0.25 \%$ sodium hypochlorite solution for 4 minutes, washed thoroughly with sterile distilled water, then blotted between sterile filter papers and plated on Potato Dextrose Agar medium (PDA). Inoculated plates were incubated at 18-20 ${ }^{\circ} \mathrm{C}$ for 10-15 days and examined daily for observing the pathogen growth. The growing pathogen formied distinguishable sclerotia, then examined microscopically and purified using the hyphal tip technique. Pure cultures were maintained on PDA slants and kept in a refrigerator at $4 \stackrel{\circ}{\circ} \mathrm{C}$ as stock cultures for further tests.

A laboratory trial was conducted at $20 \stackrel{\circ}{ } \mathrm{C}$ to determine the effect of $\mathrm{pH}$ range on the growth and sclerotial formation of $S$. cepivorum based on Kumar et al. (2004). Erlenmeyer flasks contain PDA media were calibrated and adjusted at different $\mathrm{pH}$ degrees of 4,6,7 and 8. PDA-media were poured into $9 \mathrm{~cm}$ Petri-dishes $(15 \mathrm{ml} /$ dish). Plates were inoculated in the center with discs $(1.5 \mathrm{~cm}$ in diameter) of the tested isolate of the fungus. Plates of each $\mathrm{pH}$ degree were then incubated at $20{ }^{\circ} \mathrm{C}$ using digital incubators. Experiments were done in three replicates. Growth was daily observed and measured after 7 days from inoculation time. Sclerotia formed of each plate were counted in discs (7 mm in diameter each) and their diameters were microscopically measured later after 21 days from inoculation.

\section{Compost of the wastes:}

Onion, garlic and cabbage wastes were collected from backhouses in Kafrelsheikh and El-Gharbia Governorates, Egypt. Shale-skins, peelings or chopped whole bulbs of onion and garlic top and un-marketing leaves of cabbage waste were collected. The wastes were chopped into very small pieces $(0.5 \mathrm{~cm})$ and incubated at $50{ }^{\circ} \mathrm{C}$ till the weights of the wastes become constant. This temperature seems to be suitable for drying wastes and eradicating pathogens (Bollen et. al., 1989). Dried wastes were incorporated in successive layers with farmyard manures $w / w$ in heaps form. Composted 
heaps were regular supplemented with suitable water. Turning process was also done every week with keeping the moisture within the range of 40-60\% along the composting process. After elapsing the composting process (about two months), heaps collapsed and moisten to the suitable range. Three composted waste concentrations (5, 10 and $15 \%)$ were used and added to the soil $\mathrm{w} / \mathrm{w}$. The mixtures were well homogenized and placed in pots $(30 \mathrm{~cm}$ in diameter) for greenhouse trial.

\section{Sclerotia of S. cepivorum:}

To produce large numbers of sclerotia for experiments, mycelial suspension of S. cepivorum was obtained by adding $10 \mathrm{ml}$ sterile distilled water (SDW) to 2-weeks-old PDA cultures (no sclerotia present) and scraping with a spatula and macerating the mycelial slurry in a blender with $490 \mathrm{ml}$ SDW. The slurry was used to inoculate bags contain medium consists of 960 $\mathrm{g}$ washed sand mixed with $40 \mathrm{~g}$ ground corn meal and $90 \mathrm{ml}$ water which had been autoclaved at $121^{\circ} \mathrm{C}$ for 20 minutes as described by Clarkson et al. (2004). The bags were incubated at $20^{\circ} \mathrm{C}$ for 6 weeks, after which time sclerotia had formed. Sclerotia were harvested by floatation the medium in water, decanted into a $212 \mu \mathrm{m}$ mesh diameter sieves (Coley-Smith, 1987). After that, the sclerotia were air dried for $12 \mathrm{~h}$ and stored at $5{ }^{\circ} \mathrm{C}$ for further experiments.

\section{Effect of the composted wastes on survival of sclerotia:}

100 sclerotia were placed in fine mesh polyester bags $(150 \mu \mathrm{m}$ mesh diameter). The bags were then closed, tied at the top and centered at $10 \mathrm{~cm}$ depth of the soil surface in the pots. Pots free from composted wastes were acted as control. The experiment was carried out in three replicates (pots), three sclerotial bags of each. Three bags of sclerotia were removed from each treatment after 15, 30 and 45 days exposure times. Sclerotia of each treatment were washed thoroughly with water, collected on a $212 \mu \mathrm{m}$ mesh diameter sieve, and retrieved using forceps under a binocular microscope. They were surface sterilized using sodium hypochlorite $(0.5 \%)$ solution for 1.5 minutes, rinsed in SDW four times and plated on PDA medium amended with $0.02 \mathrm{~g} \mathrm{~L}^{-1}$ chlortetracycline (powder containing $80 \%$ chlorotetracycline $\mathrm{HCL}$ ) (Williams et al., 1998). Plates were incubated for two weeks at $20{ }^{\circ} \mathrm{C}$ and then the germinated sclerotia were counted. Number of the germinated sclerotia was subtracted from 100 to calculate percentage of the nongerminated destroyed (nonviable) sclerotia as follows:

Percentage of destroyed sclerotia $=100-$ germinated sclerotia

Effect of the composted wastes on the chemical properties of the soil:

Samples of the aforementioned soil amended with each of the composted wastes were analyzed to determine their contents of $\mathrm{NH}_{4}, \mathrm{NO}_{3}, \mathrm{P}$, $\mathrm{K}$ and $\mathrm{SO}_{4}$ due to the applied treatments. Chemical analysis of the tested elements was done at Soil Science Dept., Faculty of Agric., Kafrelsheikh Uni., Egypt according to the methods described by Chapman and Pratt (1961) and Cottenie et al. (1982). 


\section{Statistical analysis:}

Data were statistically tested for analysis of variance (ANOVA) using Irristat version 3/93. A complete randomize design was applied in this study. For comparing the means, Duncan's multiple range tests were used (Duncan, 1955).

\section{RESULTS AND DISCUSSION}

\section{Effect of $\mathrm{pH}$ on growth and formation of sclerotia:}

A preliminary laboratory-based trial indicated that Sclerotium cepivorum, the causal pathogen of onion white rot disease, could be influenced due to cultivation under a wide range of $\mathrm{pH}$ values (Table 1).

Table 1. Effect of $\mathrm{pH}$ range on the mycelial growth, number and diameter measurements of sclerotia forming by $S$. cepivorum.

\begin{tabular}{|c|c|c|c|}
\hline \multirow{2}{*}{ pH } & Radial growth of & \multicolumn{2}{|c|}{ Sclerotia } \\
\cline { 3 - 4 } & mycelium per cm & Number per $\mathbf{c m}^{2}$ & Diameter per $\boldsymbol{\mu m}$ \\
\hline 4 & $7.57 \mathrm{~b}$ & $360.50 \mathrm{ab}$ & $400.00 \mathrm{a}$ \\
6 & $9.00 \mathrm{c}$ & $400.36 \mathrm{~b}$ & $370.00 \mathrm{a}$ \\
7 & $8.87 \mathrm{c}$ & $500.89 \mathrm{c}$ & $400.67 \mathrm{a}$ \\
8 & $7.17 \mathrm{a}$ & $269.51 \mathrm{a}$ & $380.67 \mathrm{a}$ \\
\hline
\end{tabular}

Averages in a column followed by a different letter are significantly different at 0.05 levels after a Duncan's multiple range tests.

Radial growth of the mycelium showed clear enhancement and reached its maximum diameter $(9.00 \mathrm{~cm})$ at $\mathrm{pH} 6$ followed by $8.87 \mathrm{~cm}$ at $\mathrm{pH} 7$ after 7 days from incubation time. Sclerotial number of 21-days old cultures was also significantly increased and reached the highest value of 500.89 and 400.36 sclerotia per $\mathrm{cm}^{2}$ at $\mathrm{pH} 7$ and $\mathrm{pH} 6$, respectively. On the other hand, the lowest radial growth and sclerotial numbers were observed at $\mathrm{pH} 8$ and $\mathrm{pH}$ 4. No-significant differences of sclerotial size were obtained under the tested $\mathrm{pH}$ range. It has been proved that there is a relationship between the mycelial biomass, number and size of the formed sclerotia. These results agree with those of Kumar et al. (2004) who found that $\mathrm{pH} 6$ followed by $\mathrm{pH} 5$ and $\mathrm{pH} 4$ were the optimal $\mathrm{pH}$ degrees for growing Sclerotinia sclerotium, but its growth was sharp decreased at $\mathrm{pH} 9$ with no sclerotial formation. They also found that the maximum growth of $S$. cepivorum was observed at $20{ }^{\circ} \mathrm{C}$ with excellent sclerotial formation. The optimal $\mathrm{pH}$ level for growth of all isolates of Colletotrichum coccodes was $\mathrm{pH} 6$ and $\mathrm{pH} 7$ (Nitzan and Tstor, 2003). Major numbers of the produced sclerotia per $\mathrm{cm}^{2}$ on PDA plates reflect the great risk of the pathogen spread to vast areas. Significant differences between $S$. cepivorum isolates in their growth rate and sclerotial number and size were demonstrated by Stewart (1990) and Lertes and Krauthausen (1994). Data reflect also that $S$. cepivorum could be grown with formation of large numbers of sclerotia at $20{ }^{\circ} \mathrm{C}$ under laboratory conditions. It indicates that temperatures less or above $20{ }^{\circ} \mathrm{C}$ are unfavorable for white 
rot development in this study, but Leggett and Rahe (1985) found that the unfavorable temperatures are at or above $22-2420^{\circ} \mathrm{C}$ for the pathogen.

\section{Effect of the prepared wastes on survival of sclerotia:}

For controlling white rot disease of onion, need to effective, environmentally safe and alternative to the synthetic fungicides are necessary. Stimulation of sclerotial germination in the absence of the host was the suggested technique, which the mycelium will starve and die. However, three concentrations of composted wastes of onion, garlic and cabbage, as sources of sulfurous compounds, were the main materials selected. Percentages of the destroyed sclerotia (failure of germination on PDA) due to the use of composted onion wastes in comparison with control were blotted in Fig. 1.

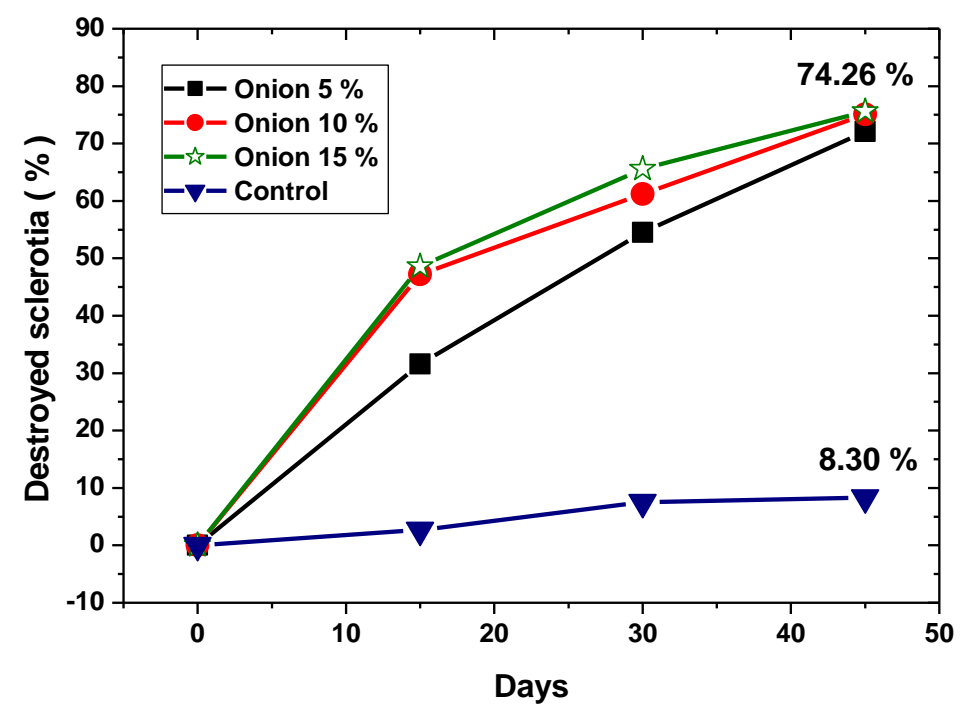

Fig. 1. Effect of different applied concentrations of composted onion wastes on destroying sclerotia formed by $S$. cepivorum during their exposure in the soil.

Results indicate that the destroyed percentages of sclerotia were gradually increased as increasing the onion concentrations and exposure time in the soil. Sclerotia were strongly destroyed due to the use of 10 and 15 $\%$ of the compost in comparison with $5 \%$ and control treatments after 15 days. After 30 days from exposure, suppressive effects of all used compost concentrations against viability of the treated sclerotia were paralleled increased in comparison with tiny or no effect showed for control. However, destroyed sclerotia reached their maximum percentages after 45 days in the soil. Because the maximum percentages were approximately pointed, average value of all tested concentrations was calculated and reached 74.26 
$\%$ in comparison with $8.30 \%$ for control. Therefore, reduced viability of the treated sclerotia (high destruction) compared with control (low destruction), indicating a great control potential of the waste.

The more pronounced effect for destroying the treated sclerotia was obtained by application of the composted garlic wastes (Fig. 2). In comparison with onion waste, the same behavior was observed by garlic compost. Data obtained by 10 and $15 \%$ were approximately similar and strongly enhanced at 15 days in comparison with $5 \%$ followed in control at the same time. After that, effect of all concentrations on the sclerotial status was parallel increased, and reached the maximum mean of destroyed percentage $(75.70 \%)$ after 45 days exposure in the soil.

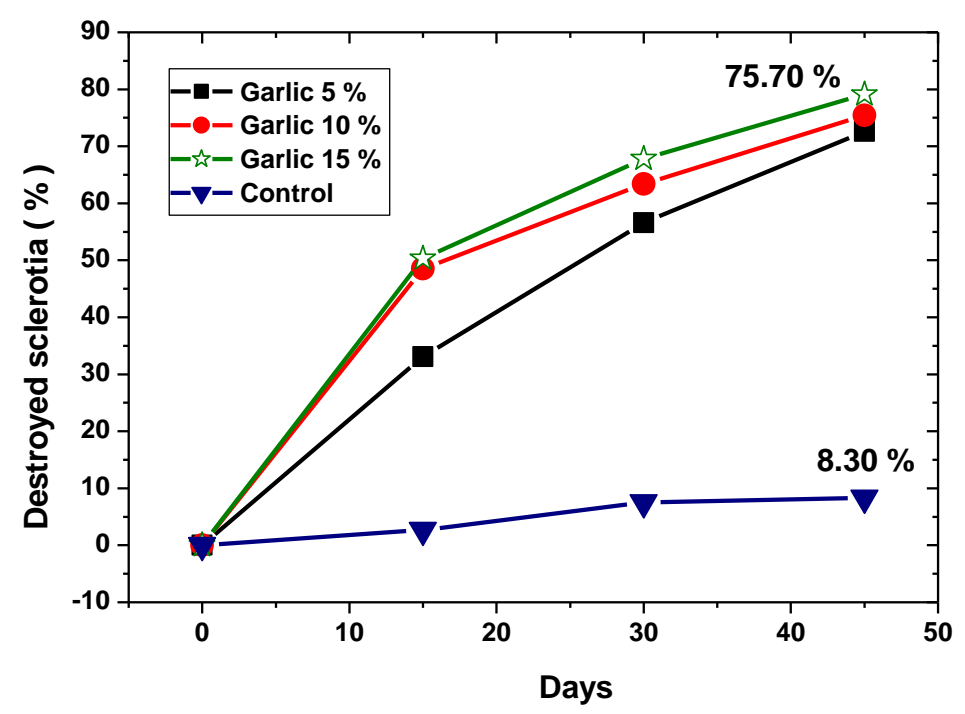

Fig. 2. Effect of different applied concentrations of composted garlic wastes on destroying sclerotia formed by S. cepivorum during their exposure in the soil.

Those results given by onion and garlic composts were similar obtained by cabbage wastes, with maximum mean efficiency reached 72.26 $\%$ after 45 days exposure in the soil (Fig. 3). From the obtained data, basic question was suggested: when the exposed sclerotia will be completely destroyed? To answer this question, and due to approximately similar behaviors were obtained, data of destroyed sclerotia resulting from all treatments during the exposed days in the soil were lineal fitted in Fig. 4. For this purpose, the linear least squares fitting routine of MicroCal's ORIGIN ${ }^{\circledR}$ software package was used. 


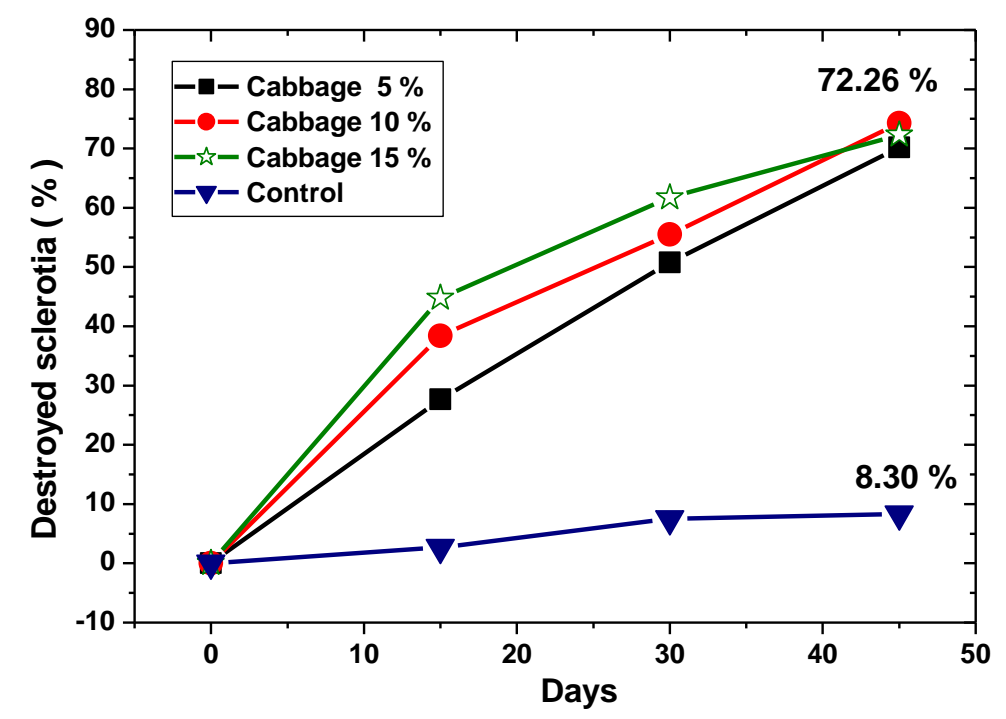

Fig. 3. Effect of different applied concentrations of composted cabbage wastes on destroying sclerotia formed by $S$. cepivorum during their exposure in the soil.

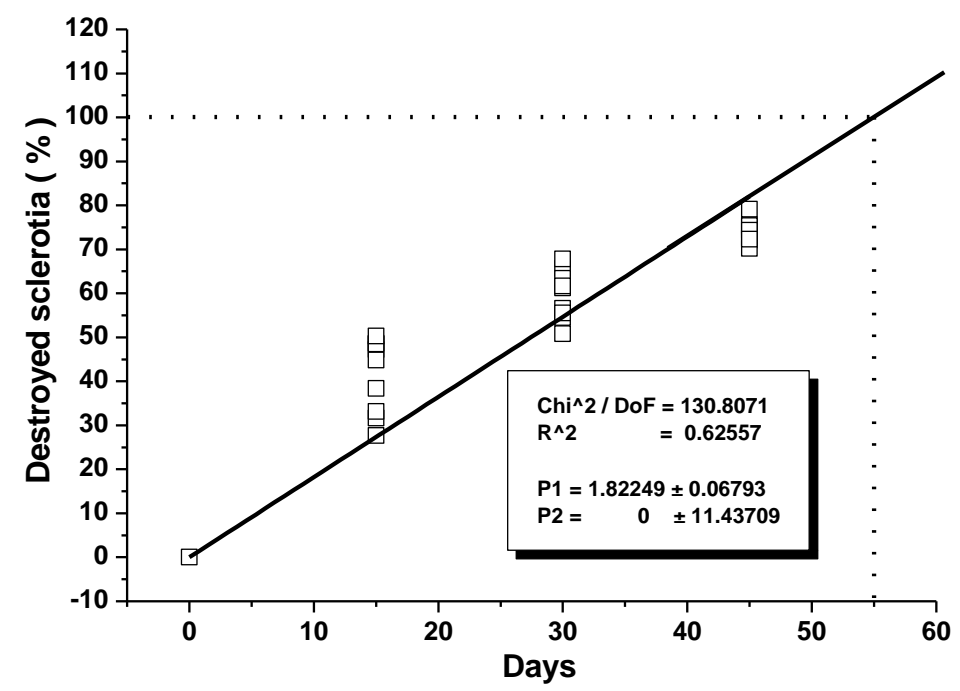

Fig. 4. Linear fitting data of S. cepivorum sclerotia destroyed after 15, 30 and 45 exposed days due to application of different concentrations of the composted wastes. 
The experimental data were good fitted and an excellent regression degree of $R^{2}$ was found. It illustrates that 55 days are required to kill (failure germination on PDA) $100 \%$ of the exposed sclerotia to each concentration of the investigated compost types in absence of the host. However, potential uses of $15 \%$ followed by $10 \%$ of the composts were rapidly done after 15 exposed days. Application of the lower concentration (5\%) was later obtained. However, destroying effects of all used concentrations of each compost type against sclerotia in absence of the host were almost similar at long period (30 and 45 exposed days). Due to similar effect, data indicated occurrence of linear response with the exposed time. The obtained results agree with Sommerville and Hall (1987) who reported that the germination of sclerotia exposed to alkyl products was a linear response with time, increasing from $15 \%$ (at 15 days) to over $55 \%$ (at 45 days). Hovius and McDonald (2002) demonstrated that the population numbers of sclerotia were reduced between 15 and 45 exposed days due to use of composting wastes, but within the first 1-3 months due to the DADS application. So, application of composted wastes of Allium species, rich in volatile compounds, was also successfully used by Coley-Smith and King (1969) and Entwistle (1994) to stimulate sclerotial germination of $S$. cepivorum. Linderman and Gilbert (1973) found a remarkable effect of the volatiles produced from plant residues (alfalfa hay) against germination of sclerotia formed by Sclerotium rolfsii. Additionally, wastes and composted wastes have been shown to provide some degree of control of a number of soil-borne pathogens (Coventry et. al., 2002 and Davis et. al., 2007).

\section{Effect of composted wastes on the soil properties:}

Table 2 showed effect of the investigated composts on the soil contents of $\mathrm{NH}_{4}, \mathrm{NO}_{3}, \mathrm{P}, \mathrm{K}$ and $\mathrm{SO}_{4}$ in comparison with the control. Accumulation of higher $\mathrm{NH}_{4}$ value reached $56.15 \mathrm{ppm}$ in the pots treated with $15 \%$ composted onion waste in comparison with $25.00 \mathrm{ppm}$ for untreated pots. The highest $\mathrm{NO}_{3}$ contents (17.29 and $17.25 \mathrm{ppm}$ ) were detected due to the use of composting onion (10\%) and garlic (5\%) wastes, respectively. Increasing formation of $\mathrm{NO}_{3}$ in relation to $\mathrm{NH}_{4}$ contents indicates higher assimilative efficacy for the organic matter of the treated soil in comparison with control. These results illustrate enhancement of the chemical properties in the treated soil which might be affect the population of sclerotia. These results are in agreement with the findings of Hovius and McDonald (2002) who stated reduction in sclerotia counts, consequently controlling onion white rot in organic soil. $\mathrm{P}$ and $\mathrm{K}$ contents showed also more accumulations reached 46.80 and $714.09 \mathrm{ppm}$, respectively in the pots treated with $15 \%$ composted onion wastes. Application of both 15 and $10 \%$ composted cabbage wastes caused higher $\mathrm{SO}_{4}$ contents (1.64 and $1.56 \mathrm{ppm}$ ) in comparison with (1.11 ppm) control. Accumulation of higher amounts of $\mathrm{SO}_{4}$ could play a role in stimulating germination of sclerotia in the soil, consequently mycelium starved and decomposed in absence of the host. The sulfide componds stimulate eruptive germination of the sclerotia after their metabolized by the soil microflora to yield a range of volatile thiols and sulfides that activate the dormant sclerotia (Sommerville and Hall, 1987). 
Table 2. Effect of composted onion, garlic and cabbage waste applications on the chemical composition of the soil comprised sclerotia of S. cepivorum.

\begin{tabular}{|c|c|c|c|c|c|c|}
\hline \multirow{2}{*}{ Treatments } & \multirow{2}{*}{ Conc. } & \multicolumn{5}{|c|}{ Chemical composition (ppm) } \\
\hline & & $\mathrm{NH}_{4}$ & $\mathrm{NO}_{3}$ & $\mathbf{P}$ & K & $\mathrm{SO}_{4}$ \\
\hline Onion & & $43.20 \mathrm{~b}$ & $14.75 a b$ & $20.00 \mathrm{a}$ & $383.67 \mathrm{~b}$ & $1.08 \mathrm{a}$ \\
\hline Garlic & $5 \%$ & $26.00 \mathrm{a}$ & $17.25 \mathrm{~b}$ & $37.30 \mathrm{c}$ & $400.14 \mathrm{bc}$ & $1.40 \mathrm{a}$ \\
\hline Cabbage & & $41.20 \mathrm{~b}$ & $12.80 \mathrm{a}$ & $26.70 \mathrm{~b}$ & $421.12 \mathrm{c}$ & $1.23 \mathrm{a}$ \\
\hline \multicolumn{2}{|l|}{ Control } & $25.00 \mathrm{a}$ & $12.50 \mathrm{a}$ & $21.60 \mathrm{a}$ & $327.60 \mathrm{a}$ & $1.11 \mathrm{a}$ \\
\hline Onion & & $38.65 \mathrm{~b}$ & $17.29 \mathrm{c}$ & $27.50 \mathrm{~b}$ & $494.91 \mathrm{~b}$ & $1.23 \mathrm{ab}$ \\
\hline Garlic & $10 \%$ & $44.25 \mathrm{c}$ & $15.10 \mathrm{bc}$ & $38.00 \mathrm{c}$ & $485.94 \mathrm{~b}$ & $1.43 \mathrm{bc}$ \\
\hline Cabbage & & $43.30 \mathrm{c}$ & $14.20 a b$ & $26.80 \mathrm{~b}$ & $500.10 b$ & $1.56 \mathrm{c}$ \\
\hline \multicolumn{2}{|l|}{ Control } & $25.00 \mathrm{a}$ & $12.50 \mathrm{a}$ & $21.60 \mathrm{a}$ & $327.60 \mathrm{a}$ & $1.11 \mathrm{a}$ \\
\hline Onion & & $56.15 \mathrm{~d}$ & $16.72 \mathrm{~b}$ & $46.80 \mathrm{~d}$ & $714.09 \mathrm{c}$ & $1.49 \mathrm{~b}$ \\
\hline Garlic & $15 \%$ & $37.80 \mathrm{~b}$ & $16.00 \mathrm{ab}$ & $31.30 \mathrm{c}$ & $503.35 \mathrm{~b}$ & $1.47 \mathrm{~b}$ \\
\hline Cabbage & & $50.10 \mathrm{c}$ & $15.00 \mathrm{ab}$ & $24.60 \mathrm{~b}$ & $553.31 \mathrm{~b}$ & $1.64 \mathrm{~b}$ \\
\hline \multicolumn{2}{|l|}{ Control } & $25.00 \mathrm{a}$ & $12.50 \mathrm{a}$ & $21.60 \mathrm{a}$ & $327.60 \mathrm{a}$ & $1.11 \mathrm{a}$ \\
\hline
\end{tabular}

Averages in a column followed by a different letter are significantly different at 0.05 level after a Duncan's multiple range test.

These results indicate that applications of composted plant wastes in absence of the host could be attributed as an effective technique not only to destroy the sclerotia but also to prevent their spread to the neighboring fields. Moreover, soil type and its contents may play an additional role in timing of sclerotial response to germination stimulants. Accordingly, produced mycelium was starved and finally damaged without production of more sclerotia. Hovius and McDonald (2002) and Davis et. al. (2007) referred that the stimulating of sclerotial germination in absence of Allium crops followed by starvation of the productive mycelium and destroying it. Block et al. (1992) detected thiosulphinates in fresh onion which could be produced as secondary products resulting from metabolism of DADS and DPDS of soil microflora. However, other factors seem probably to be more important than the germination stimulant activity of the sclerotia for suppressing $S$. cepivorum by the composting waste applications. Therefore, further research is needed to determine the effectiveness of these treatments under different disease severities.

\section{REFERENCES}

Banks, E. and L. V. Edgington (1989). Integrated control of Sclerotium cepivorum Berk in organic soils. Can. J. Plant Pathol., 11: 268-272.

Block, E.; D. Putman; S. H. Zhao (1992). Allium chemistry: GC-MS analysis of thiosulphinates and related compounds from onion, leek, scallion, shallot, chive, and Chinese chive. J. of Agric. and Food Chemistry, 40: 2431-2438.

Bollen, G. J.; D. Volker and A. P. Wijnen (1989). Inactivation of soil-borne plant pathogens during small-scale composting of crop residues. Netherlands Journal of Plant Pathol., 95(supplement 1): 19-30. 
Chapman, H. D. and P. M. Pratt (1961). Methods of analysis for soils, plants and water. Univ. of California, Riverside, USA.

Clarkson, J. P.; A. Mead; T. Payne and J. M. Whipps (2004). Effect of environmental factors and Sclerotium cepivorum isolate on sclerotial degradation and biological control of white rot by Trichoderma. Plant Pathol., 53: 353-362.

Clarkson, J. P.; T. Payne; A. Mead and J. M. Whipps (2002). Selection of fungal biological control agents of Sclerotium cepivorum for control of white rot by sclerotial degradation in a UK soil. Plant Pathol., 51: 735745.

Coley-Smith, J. R. (1987). Alternative methods of controlling white rot disease of Allium. In: Chet, I. (Ed.). Innovative Approaches to Plant Disease Control. Wiley, New York, pp. 161-177.

Coley-Smith, J. R. and D. Parfitt (1986). Some effects of diallyl disulphide on sclerotia of Sclerotium cepivorum: possible novel control method for white rot disease of onions. Pesticide Science, 37: 587-594.

Coley-Smith, J. R. and J. E. King (1969). Production of volatile alkyl sulphidesby microbial degradation of synthetic alliin and alliin-like compounds, in relation to germination of sclerotia of Sclerotium cepivorum Berk. Ann. Appl. Biol., 64: 303-314.

Cottenie, A.; M. Verloo; L. Kiekens; G. Velghe and R. Camerlýnck (1982). Chemical analysis of plant and soil. Laboratory of analytical and agrochemistry. State Univ. Ghent., Belgium, pp: 100.

Coventry, E.; R. Noble; A. Mead and J. M. Whipps (2002). Control of Allium white rot (Sclerotium cepivorum) with composted onion waste. Soil Biology and Biochemistry, 34: 1037-1045.

Crowe, F. J. and D. H. Hall (1980). Soil temperature and moisture effects on sclerotium germination and infection of onion seedlings by Sclerotium cepivorum. Phytopathol., 70: 74-78.

Crowe, F.; J. Debons; T. Darnell; M. Thornton; D. McGrath; P. Koepsell; J. Laborde and J. Redondo (1994). Control of Allium white rot with DADS and related products. In Proceedings of the $5^{\text {th }}$ International Workshop on Allium white rot. Cordoba, Spain. HRI, Wellesborne, Warwick, U. K.

Davis, R. M.; J. J. Hao and M. K. Romberg (2007). Efficacy of germination stimulants of sclerotia of Sclerotium cepivorum for management of white rot of garlic. Plant Dis., 91: 204-208.

Duncan, D. B. (1955). Multiple range and multiple F. test. Biometrics, II: 1-42.

Entwistle, A. R. (1990). Allium white rot and its control. Soil Use and Management, 6: 201-204.

Entwistle, A. R. (1994). The dynamics of Sclerotium cepivorum inocula: a theoretical framework. In: Entwistle, A. R., Meloro-Vera, J. M. (Eds). $5^{\text {th }}$ International workshop on Allium white rot. Instituto de Agricultura Sostenible, Cordoba, pp. 40-47.

Hadler, Y. and B. Gorodecki (1991). Suppression of germination of sclerotia of Sclerotium rolfsii in compost. Soil Biology and Biochemistry, 23: 303306. 
Hovius, M. H. Y. and M. R. McDonald (2002). Management of Allium white rot (Sclerotium cepivorum) in onions on organic soil with soil-applied diallyl disulfide and di- $N$-propyl disulfide.Can. J. Plant Pathol., 24: 281-286.

Kumar, B.; R. Pandey and A. K. Verma (2004). Effect of temperature and pH on growth and sclerotial formation of Sclerotinia sclerotium causing stem and root rot of broccoli. CABI, Society for Recent Devel. in Agr., http://www.cababstractsplus.org/abstracts/Abstract.aspx?AcNo=20043 186761

Leggett, M. E. and J. E. Rahe (1985). Factors affecting the survival of sclerotia of Sclerotium cepivorum in the Fraser Valley of British Columbia. Ann. Appl. Biol., 106: 255-263.

Lertes, B. and H. J. Krauthausen (1994). Variability of Sclerotium cepivorum isolates in Rhineland Palatine, Germany. In proceedings of the Fifth International Workshop on Allium white rot 1994. Cordoba, Spain, pp. 44-48.

Linderman, R. G. and R. G. Gilbert (1973). Influence of volatile compounds from alfalfa hay on microbial activity in soil in relation to growth of Sclerotium rolfsii. Phytopathol., 63: 359-362.

McLean, K. L.; J. Swaminathan and A. Stewart (2001). Increasing soil temperature to reduce sclerotial viability of Sclerotium cepivorum in New Zealand soils. Soil biology and biochemistry, 33: 137-143.

Melero-Vara, J. M.; A. M. Prados-Ligero and M. J. Basallote-Ureba (2000). Comparison of physical, chemical and biological methods of controlling garlic white rot. European journal of Plant Pathol., 106: 581-588.

Nitzan, N. and L. Tstor (Lahkim) (2003). Effect of temperature and pH on in vitro growth rate and sclerotial density of Colletotrichum coccodes isolates from different VCGs. American J. Potato Res., 80: 95-99.

Sommerville, P. and D. H. Hall (1987). Factors affecting sclerotial germination of Sclerotium cepivorum, secondary sclerotial formation, and germination stimulants to reduce inoculum density. Plant Dis., 71: 229233.

Stewart, A. (1990). Isolate variation in Sclerotium cepivorum. In proceedings of the $4^{\text {th }}$ International Workshop on Allium white rot 1990. Neustandt/Weinstrasse, Fedral Republic of Germany, pp. 86-90.

Stewart, A.; R. A. Fullerton and P. W. Sutherland (1989). Infection of onion by the white rot pathogen, Sclerotium cepivorum. J. Phytopathol., 38: 315322.

Stewrat, A.; E. A. Slade and R. A. Fullerton (1994). Chemical control of onion white rot in New Zealand. In: Entwistle, A. R., Melero-Vara, J. M., (Eds.). Fifth International Workshop on Allium White rot. Instituto de Agricultura Sostenible, Cordoba, pp. 166-168.

Utkheda, R. S. and J. E. Rahe (1982). Treatment of muck soil with onion oil to control onion white rot. Can. J. Plant Pathol., 4: 78-80.

Williams, P. H.; J. M. Whipps and R. C. Cooke (1998). Role of soil mesofauna in dispersal of Coniothyrium minitans: mechanisms of transmission. Soil Biology and Biochemistry, 30: 1937-1945. 
مقاومـة العفن الأبيض في أنواع جنس Allium المتسبب عن Sclerotium

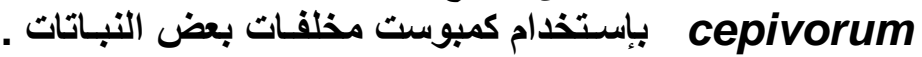

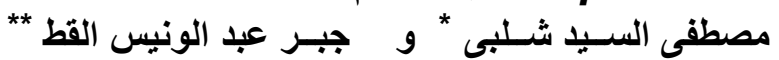

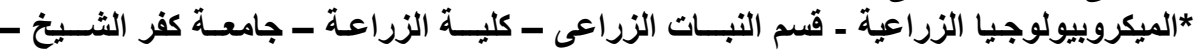

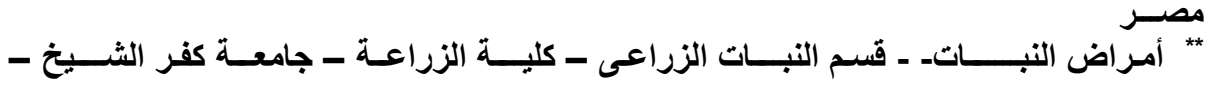
مصسر

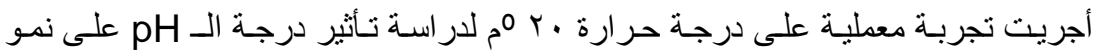

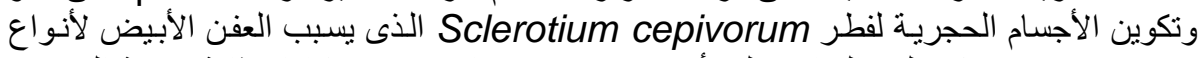

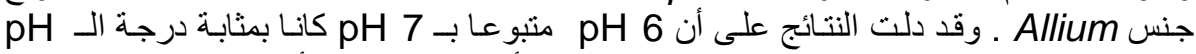

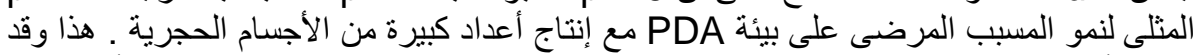

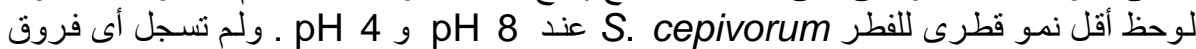

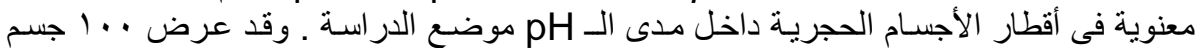

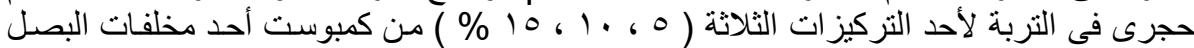

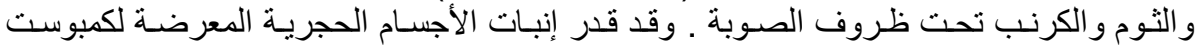

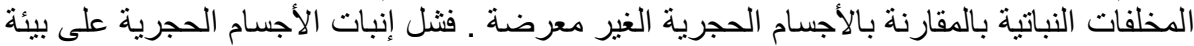

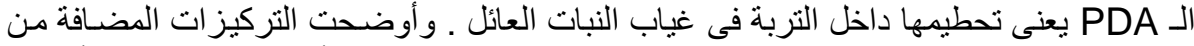

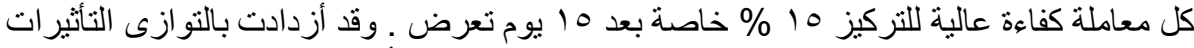

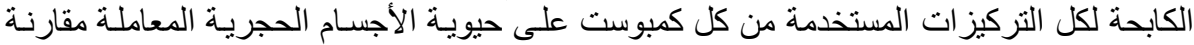

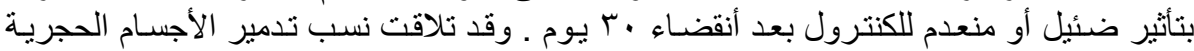

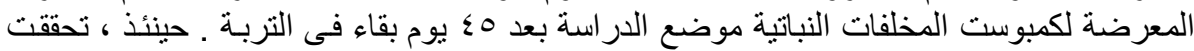

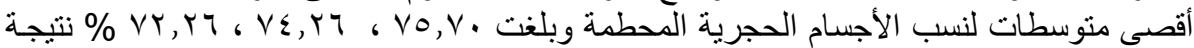

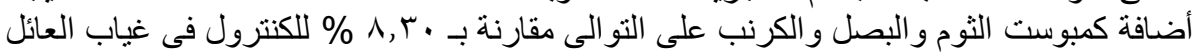

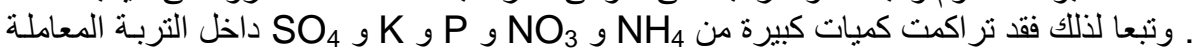

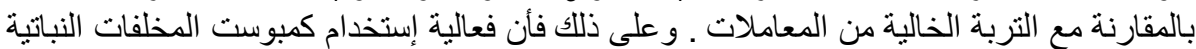

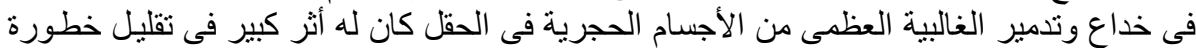

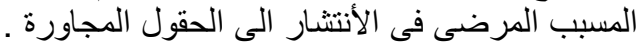

